Jurnal Ilmu Administrasi Publik 7 (2) (2019): 42-57

DOI: http://dx.doi.org/10.31289/publika.v7i2.2822

Jurnal Administrasi Publik

http://ojs.uma.ac.id/index.php/publikauma

\title{
Deradikalisasi Teroris melalui Lapas Supermaksimum Security dari Perpective Implementasi Kebijakan
}

\author{
Dian Eko Rini*, Teguh Kurniawan ** \\ **Program Studi Ilmu Administrasi, Pasca Sarjana \\ Fakultas Ilmu Administrasi, Universitas Indonesia
}

Diterima Agustus 2019; Disetujui Oktober 2019; Dipublikasikan Desember 2019

\begin{abstract}
Abstrak
Terorisme sebagai kejahatan 'ideologi' telah menjadi ancaman bagi lapas, termasuk dengan beberapa kejadian radikalisme di dalam lapas minimum security. Penelitian ini bertujuan untuk mendeskripsikan implementasi kebijakan lapas supermaksimum security di Lapas Kelas IIA pasir Putih dalam rangka mewujudkan revatilisasi pemasyarakatan. Peneliti menggunakan teori yang disampaikan oleh Grindle sebagai panduan terkait implementasi kebijakan. Peneliti menggunakan metode kualitatif dengan melakukan wawancara dan tinjauan pustaka untuk mengumpulkan dokumen-dokumen tentang penerapan kebijakan lapas risiko tinggi dalam rangka mewujudkan sistem pemasyarakatan. Hasil penelitian menunjukkan bahwa implementasi kebijakan lapas keamanan super maksimum dalam rangka mewujudkan revatilasisasi pemasyarakatan memberikan hasil yang positif bagi kelompok sasaran. Mengingat penerapananya yang masih 2 tahun berjalan, baik dalam konteks implementasi dan isi kebijakan masih diperlukan usaha lebih maksimal. Meskipun dapat dikatakan bahwa dua aspek tersebut sudah mengarah terlaksana kebijakan yang baik untuk mendapatkan hasil yang diharapkan.
\end{abstract}

Kata kunci : Radikalisme, Narapidana Resiko Tinggi, Pemasyarakatan

\section{Abstract}

Terrorism as an 'ideological' crime has become a threat to prisons, including in some incidents of radicalism in prisons, minimum security. This research aims to describe the implementation of supermaximum prison security policies in Class IIA Pasir Putih Prison in order to realize penal revitalization. Researchers use the theory presented by Grindle as a guide related to policy implementation. Researchers used qualitative methods by interviewing and evaluating literature to collect documents about the application of high risk prison policies in order to realize the penal system. The results of the study prove that the implementation of the super maximum security prison policy in order to realize correctional correctionalisation provides positive results for the target group. Remember that the application is still running for 2 years, both in the implementation and contents of the policy still need more maximum effort. Two aspects should be agreed upon which should have been a good policy to get the expected results.

Keywords : radicalism, high risk prisoners, corrections

How to Cite : Rini., E.D dan Kurniawan, T. (2019). Deradikalisasi Teroris melalui Lapas Supermaksimum Security dari Perpective Implementasi Kebijakan, 7 (2) : 42-57
*Corresponding author:
E-mail: dianekorini@gmail.com
P-ISSN-2549-9165
e-ISSN -2580-2011 


\section{PENDAHULUAN}

Pembangunan lapas super maksimum security bukanlah hal yang baru dalam kebijakan pemasyarakan ranah internasional. Bila di Indonesia, lapas supermaksimum security baru dioperasikan diakhir 2017, maka sangat berbeda dengan negara-negara di Dunia khususnya Negara Amerika.

Menurut (Mears, 2008), penjara supermaksimum security telah muncul dalam 25 tahun terakhir sebagai salah satu kebijakan peradilan pidana yang paling simbolis. (Henningsen, Johnson, \& Wells, 1999) menjelaskan bahwa penjara supermaksimum security di Amerika juga digunakan untuk memisahkan pengacau paling serius dan kronis dari populasi penjara umum. Hal tersebut tentu memperkuat alasan pembangunan lapas supermaksimum security di Indonesia sebagai kebijakan yang dinanti untuk menyelesaikan permasalahan crusial pemasyarakatan, salah satunya adalah permasalahan keamanan dan ketertiban di dalam lapas, khususnya untuk terorisme.

Sejatinya permasalahan terorisme bukan hanya berhenti sampai dengan pemidanaan teroris di penjara. Upaya penangkapan yang dilakukan Densus 88
AT / Polri hingga pembinaan di lembaga pemasyarakatan (lapas) seolah tidak memiliki efek jera apapun dan membuat paham radikal yang melekat pada teroris hilang, bahkan radikalisasi itupun dapat terjadi di dalam penjara. Menurut (Hassan dan Yassin, 2012) menyebutkan bahwa tanpa sistem dan manajemen penjara yang konsisten dan efektif, tindakan melanggar hukum berlanjut di penjara dan narapidana terorisme telah menjadikan penjara Indonesia sebagai tempat berkembang biak bagi kegiatan terkait terorisme. Di dalam penjara minimum security, narapidana terorisme ekstremis dengan leluasa dapat merekrut para narapidana kejahatan lain untuk menjadi simpatisannya dan mereka pun tetap dapat mempertahankan kontak dengan dunia luar penjara untuk terlibat dalam kegiatan yang halus namun merusak keamanan Indonesia tanpa sepengetahuan petugas lapas.

Radikalisasi terorisme di dalam penjara tidak terlepas dari karakteristik yang berbeda dengan narapidana pada umumnya. Menurut (Firdaus, 2017), narapidana terorisme cenderung tidak mau berbaur dan tidak kooperatif dengan petugas dan berpotensi menyebarkan paham radikalisme ke narapidana lainnya 
atau bahkan kepada petugas pemasyarakatan. Oleh sebab itu pembinaan terhadap narapidana teroris harus mendapatkan perlakuan yang bersifat khusus, dalam arti bahwa perlakuan terhadap narapidana kasus terorisme tidak dapat dipersamakan dengan perlakuan terhadap narapidana kasus lainnya.

Terjadinya radikalisasi terhadap keluarga, pendukung dan narapidana lain oleh para Narapidana terorisme di dalam penjara menjadikan sebuah dilema bagi petugas pemasyarakatan. Dalam Laporan IPAC (Institute for Analysis of Conflict) Nomor 34 Tahun 2016 disampaikan bahwa para narapidana terorisme radikal, yang termasuk sebagai ideolog, dapat mengendalikan pengikut mereka tidak hanya di dalam lapas Pulau Nusakambangan tetapi juga yang berada di luar melalui instruksi dan fatwa yang disebarkan melalui media telepon genggam yang telah mereka selundupkan kedalam lapas untuk merekam dan menyiarkan langsung kepada pendukung yang berada di luar lapas. Bahkan untuk perencanaan aksi teror baik dari persiapan, pendanaan hingga perintah untuk menjadi "pengantin" juga dibahas di oleh para ideolog, yang sedang menjalani hukuman di dalam lapas.

Pengoperasian lapas supermaksimum security pun digunakan untuk melakukan sistem pemasyarakatan kepada narapidana high risk. Melalui Keputusan Menteri Hukum dan HAM No. M.HH-07.0T.01.01 Tahun 2017 tentang Penetapan Lapas Batu, Lapas Pasir Putih, Lapas Narkotika Langkat, Lapas Narkotika Kasongan, Rutan Gunung Sindur sebagai Lapas dan Rutan Khusus bagi Napi atau Tahanan Resiko Tinggi (High Risk), maka dalam rangka optimaliasasi pelaksanaan sistem pemasyarakatan selanjutnya ditetapkan Lapas Batu, Lapas Pasir Putih, Lapas Narkotika Langkat, Lapas Narkotika Kasongan, Rutan Gunung Sindur sebagai lapas dan rutan khusus bagi narapidana atau tahanan resiko tinggi (high risk).

Narapidana resiko tinggi yang dimaksud disini adalah narapidana yang berdasarkan penilaian dengan klasifikasi resiko dan indikator tertentu pada aspek keamanan, aspek keselamatan, aspek stabilitas, dan aspek relasi dengan masyarakat (Keputusan Menteri No. M.HH-02.PK.01.02.02 Tahun 2017 tentang Pedoman Kerja Lembaga Pemasyarakatan khusus bagi Narapidana Resiko Tinggi (High Risk) Kategori Teroris). Diantara 
lima UPT yang ditunjuk sebagai lapas high risk, Lapas Kelas IIA Pasir Putih ditetapkan sebagai lapas high risk untuk terorisme.

Pertimbangan pemilihan Lapas Kelas IIA Pasir Putih sebagai lapas high risk terorisme tentu tidak lepas dari aspek historis, mengingat para ideolog terorisme seperti Abu Bakar Baasyir, Aman Abdrurahman sudah terlebih dahulu menempati lapas ini. Sebelum ada Penetapan Keputusan Menteri Hukum dan HAM No. M.HH-07.OT.01.01 Tahun 2017 tentang Penetapan Lapas Batu, Lapas Pasir Putih, Lapas Narkotika Langkat, Lapas Narkotika Kasongan, Rutan Gunung Sindur sebagai Lapas dan Rutan Khusus bagi Napi atau Tahanan Resiko Tinggi (High Risk), Lapas Kelas IIA Pasir Putih sudah dijadikan lapas isolasi dikarenakan letak geografisnya yang berada di ujung pulau Nusakambangan. Lokasi lapas sangat minim dari akses kehidupan luar, fasilitas lapas yang juga sudah memiliki sel-sel isolasi, serta dorongan pelaksanaan revitalisasi pemasyarakatan yang menjadikan pulau Nusakambangan sebagai pilot project menjadikan alasan kuat mengapa Lapas Kelas IIA Pasir Putih di legitimasi sebagai lapas hight risk terorisme yang satu-satunya di Indonesia.
Setelah penetapan lapas high risk terorisme pada Lapas Kelas IIA Pasir Putih maka Lapas Kelas IIA Pasir Putih harus juga memiliki standar penjara supermaksimum security seperti di negara-negara lain. Riveland (1999) menyebutkan bahwa penjara-penjara ini menampung para narapidana di sel isolasi, dengan kontak minimal dengan manusia lain dan hampir tidak ada program pendidikan, agama, atau lainnya. Hal tersebut senada dengan pernyataan (Angelone, 1999) bahwa narapidana dikurung di sel selama 22 atau 23 jam dalam sehari dan membatasi kontak manusia untuk memisahkan narapidana yang paling berbahaya yang bertujuan melindungi staf penjara dan narapidana di populasi penjara umum. Lebih lanjut, penjara supermaksimum security menyatakan bahwa kekerasan dari lembaga-lembaga ini menghalangi narapidana lain untuk melakukan tindakan kriminal di dalam penjara.

Dengan semangat revitalisasi pemasyarakatan yang sedang digalakkan oleh Direktorat Pemasyaratan, kebijakan lapas high risk terorisme di Lapas Kelas IIA Pasir Putih membawa harapan baru untuk Indonesia memiliki lapas yang komprehensif, khususnya dalam 
penanggulangan radikalisasi di dalam penjara umum oleh para narapidana terorisme ideolog.

Namun kenyataannya, secara teoritis dan praktis, kebijakan lapas high risk terorisme pada Lapas Kelas IIA Pasir Putih mengimplikasikan banyak hal. Insfrastruktur sistem keamanan harus dipastikan sudah tersedia dan berjalan dengan baik, dimana insfrastruktur itu pun sudah di hubungan dengan IT yang mumpuni yang mendorong para petugas lapas untuk memiliki kemampuan untuk mengoperasikannya. Sehingga kompetensi bagi para petugas lapas di Lapas Kelas IIA Pasir Putih menjadi point penting mengingat sebagian dari petugas baru di lapas ini adalah perekrutan CPNS di tahun 2017.

Selain itu, keberadaan lapas high risk juga membutuhkan sumber daya pegawai yang lebih banyak dibanding dengan lapas pada umumnya, dimana petugas pemasyarakatan tidak hanya bertugas untuk monitoring keamanan yang intens namun juga memiliki tugas untuk memonitoring para narapidana terorisme per seorangan, berbeda pada lapas umumnya yang pelaksanaan dilakukan berkelompok.
Dari permasalahan-permasalahan tersebut di atas menjadi hal yang menarik bagi peneliti bahwa keberadaan lapas high risk terorisme yang telah ditetapkan dalam Peraturan Menteri Hukum dan HAM namun belum ada kajian mengenai bagaimana implementasi atas kebijakan penjara high risk terorisme tersebut. Analisis implementasi kebijakan ini akan melihat keberhasilan kebijakan lapas high risk terorisme yang telah dibuat oleh regulator, dalam hal ini Kementerian Hukum dan HAM dan Direktorat Pemasyaraktan sebagai unit teknis bagian pemasyaraktan.

Keberhasilan implementasi dari kebijakan lapas high risk di Lapas Klas IIA Pasir Putih, kemudian dapat ditentukan oleh tingkat implementability kebijakan itu sendiri. Grindle menyebutkan ada dua faktor dalam menentukan keberhasilan implementasi kebijakan yaitu substansi kebijakan (content of policy) dan konteks implementasi kebijakan (context of implementation).

\section{METODE PENELITIAN}

Dalam penelitian ini, peneliti menggunakan pendekatan postpositivism. Pendekatan postpositivism dipilih dalam penelitian ini untuk memperoleh suatu pemahaman yang mendalam dan 
komprehensif terkait fakta-fakta yang ada dengan menggunakan alur deduktif ke induktif, yaitu penelitian berawal dari suatu teori. Sehingga pendekatan ini akan membantu untuk menganalisa pengimplementasian kebijakan lapas supermaksimum security untuk Narapidana High Risk Terorisme dilihat dari sisi substansi kebijakan (content of policy) dan konteks implementasi kebijakan (context of implementation).

Menurut (Creswell, 2014) mengemukakan bahwa dalam penelitian postpositivism seorang peneliti mengawali penelitian dengan teori. Kemudian dilanjutkan dengan pengumpulan data baik yang mendukung teori maupun yang tidak, untuk menghasilkan tujuan penelitian yang telah ditetapkan. Oleh karena itu, mengembangkan observasi dan penelitian individu merupakan salah satu tolak ukur temuan penelitian postpositivism.

Pada penelitian ini, penulis menggunakan teori dari Grindle yang telah memperkenalkan model implementasi sebagai proses politik dan administrasi. Model tersebut menggambarkan proses pengambilan keputusan yang dilakukan oleh berbagai aktor, dimana keluaran akhirnya ditentukan baik oleh materi program yang telah dicapai maupun melalui interaksi para pembuat keputusan dalam konteks politik administratif. Proses politik akan tampak melalui proses pengambilan keputusan yang melibatkan aktor kebijakan, sementara proses administasi tampak melalui proses umum mengenai aksi administratif yang dapat diteliti pada tingkat program tertentu.

Lebih lanjut Grindle menyatakan bahwa kegiatan program yang telah didesain dan pembiayaan yang memadai menentukan keberhasilan suatu proses implementasi kebijakan dalam mencapai hasil (outcomes). Sedangkan faktor-faktor yang berpengaruh dalam proses implementasi adalah Isi Kebijakan (The Content of Policy) dan Konteks implementasi (The Context of Implementation). Content of Policy mencakup 1) interests affected;2) type of benefits; 3) extent of change envisioned; 4) site of decision making; 5) program Implementors; 6) resources committe. Sedangkan the Context of Implementation mencakup: 1) power, interests, and strategies of actors involved; 2) institution and regime characteristics; 3) compliance and responsiveness 
Dilihat dari teknik pengumpulan data, penelitian ini menggunakan teknik pengumpulan data kualitatif, yaitu dengan melakukan wawancara mendalam dan studi kepustakaan dengan mengumpulkan dokumen-dokumen yang relevan dengan permasalahan yang dibahas. Studi literatur dilakukan dengan mengumpulkan dokumen, peraturan perundang-undangan, buku, data statistik dan data lain yang berhubungan dengan kebijakan lapas high risk terorisme.

Proses analisis data dimulai dengan menelaah seluruh data yang tersedia dari berbagai sumber, baik wawancara maupun dengan dokumentasi. Lebih lanjut, aktivitas dalam analisis data kualitatif dilakukan secara interaktif dan berlangsung secara terus menerus sampai tuntas, sehingga datanya jenuh (Miles \& Huberman, 1994).

Sehingga dapat dideskripsikan bahwa teknik analisis data di dalam penelitian ini dimulai ketika seluruh data, terkait implementasi kebijakan lapas high risk terorisme di Lapas Kelas IIA Pasir Putih Nusakambangan yang berasal dari berbagai sumber (wawancara dan dokumentasi) telah terkumpul (data collection). Setelah itu, kemudian data direduksi (data reduction) dengan cara merangkum, memilih hal-hal yang pokok, memfokuskan pada hal-hal yang penting, dan dicari tema dan polanya. Dengan demikian data yang telah direduksi akan memberikan gambaran yang lebih konkret mengenai implemetasi kebijakan bagi lapas supermaksimum security untuk narapidana high risk terorisme dan mempermudah peneliti untuk melakukan tahapan analisis data selanjutnya.

Tahapan analisis data selanjutnya ialah penyajian data (data display). Penyajian data ialah penyusunan seluruh data yang telah tereduksi sehingga dapat memberi kemungkinan adanya penarikan kesimpulan dan penarikan tindakan. Dalam penelitian kualitatif, penyajian data bisa dilakukan dalam bentuk uraian singkat, bagan, hubungan antar kategori, flowchart, dan lain-lain. Dalam penelitian ini, secara teknis data-data akan disajikan dalam bentuk teks naratif, tabel, foto, dan bagan. Adapun tahapan yang terakhir ialah penarikan kesimpulan/verifikasi (conclusion drawing /verification). Penarikan kesimpulan/verifikasi dalam penelitian ini akan dilakukan dengan cara mendiskusikan data-data hasil temuan yang telah disajikan dengan teori-teori yang dimasukan dalam tinjauan pustaka. 


\section{HASIL DAN PEMBAHASAN}

Kebijakan lapas supermaksimum security bagi narapidana kategori resiko tinggi (high risk) terorisme harus mampu diimplementasikan dengan baik di Lapas Kelas IIA Pasir Putih, sehingga tujuan untuk men-deradikalisasi para ideolog terorisme dapat terlaksana. Oleh karena itu, dalam menjalankan kebijakan ini dibutuhkan analisis terhadap faktorfaktor yang mempengaruhi keberhasilan implementasi kebijakan lapas supermaksimum security yang digagas oleh Grindle(1980).

\section{Isi Kebijakan (Context of Policy)}

Kategori Isi kebijakan sebagai salah satu faktor keberhasilan implementasi kebijakan selain konteks implementasi, diamati pada 6 sub kategori, yaitu: 1) interests affected; 2) type of benefits; 3) extent of change envisioned; 4) site of decision making; 5) program Implementors; 6) resources committe. Uraian berikut merupakan hasil wawancara mendalam dengan para informan pada masing-masing sub kategori pada Kategori Isi Kebijakan terkait dalam kebijakan lapas high risk terorisme di Lapas Kelas IIA Pasir Putih.

\section{Kepentingan yang Terpengaruh} (Interests Affected)

Dalam kepentingan yang terpengaruh, lihat siapa yang terlibat dan sejauh mana pengaruh kepentingan terhadap implementasi kebijakan. Kepentingan siapa yang terpengaruh adalah salah satu faktor penting dalam menerapkan kebijakan publik. Ini terjadi karena pelaksana program atau organisasi pelaksana mencoba mengidentifikasi masalah yang terjadi pada kelompok sasaran. Dalam menerapkan kebijakan penjara keamanan supermaksimum, kelompok sasaran adalah narapidana terorisme berisiko tinggi dan staf pemasyarakatan.

Berdasarkan hasil interview, didapatkan informasi bahwa implementasi kebijakan lapas supermaksimum security untuk terorisme yang dilakukan di Lapas Kelas IIA Pasir Putih berpengaruh kepada kepentingan yang terkena dampak yaitu kepentingan dalam penyelenggaraan tugas pemasyarakatan di Indonesia. Hal itu sejalan dengan penyataan dari Direktur Pembinaan Narapidana dan Latihan Kerja Produksi sebagai berikut: 
“...Yang jelas kepentingan penyelenggaraan tugas dimana pemasyarakatan mendapatkan isuisu tentang penyebaran narkoba dan penyebaran paham radikalisme yang perlu diselesaikan. Yang mana bandarbandar tersebut harus diberlakukan khusus supaya tidak melakukan pengendalian penyebaran narkoba. Teroris agar tidak menyebarkan paham-paham radikalnya terhadap narapidana lain atau kepada petugas kami. Sehingga perlu penanganan khusus. Oleh karena itu pak Menteri menetapkan lapas supermaksimum security."

Implikasi dari kebijakan ini di Lapas Kelas IIA Pasir Putih adalah bahwa ada perubahan besar dalam standar operasional, infrastruktur penjara dari penjara umum menjadi keamanan super. Tidak hanya itu, untuk staf di Lapas Kelas IIA Pasir Putih harus berdasarkan hasil penilaian sehingga ada banyak mutasi staf dari dan ke Lapas Kelas IIA Pasir Putih. Kemudian Lapas Kelas IIA Pasir Putih ditempati oleh narapidana terorisme berisiko tinggi dari semua wilayah penjara Indonesia. Bagi para narapidana terorisme yang ditempatkan di lapas, tentu saja mereka sangat terkejut mengingat lapas ini sangat berbeda dengan lapas pada umumnya. Kepala Lapas Kelas II A Pasir
Putih menyampaikan bahwa terdapat Perbedaan Pola Pembinaan Lapas High Risk yaitu
a. One man one cell;
b. Ibadah sholat sepenuhnya dilakukan dikamar;
c. Pelayanan pakaian menggunakan sistem laundry;

d. Pelayanan makan menggunakan sistem catering;

e. Kunjungan dilaksanakan satu kali satu bulan;

f. Mendapatkan hak rekreasi 1 (satu) jam perhari.

g. Kebutuhan dasar sehari-hari diberikan oleh Lapas. (Adanya tenaga outsourching untuk kegiatan tersebut)

Dengan adanya perbedaan dalam pembinaan lapas high risk tersebut maka Narapidana harus menempati satu sel satu narapidana, di mana semua kegiatan harus dilakukan di dalam sel, selain itu kontak dengan staf lapas atau kunjungan keluarga sangat terbatas. Gejolak penolakan oleh narapidana dengan sistem keamanan ini sangat jelas, tetapi secara bertahap ada perubahan yang diharapkan dari penerapan Lapas Kelas IIA Pasir Putih. 
Berdasarkan penjelasan di atas, dapat disimpulkan bahwa kepentingan yang terkena dampak dalam pelaksanaan kebijakan supermaksimum security di Lapas Kelas IIA Pasir Putih adalah kepentingan negara, terutama lembaga yang terlibat dalam pencegahan dan pengendalian terorisme seperti Kementerian Hukum dan Hak Asasi Manusia melalui Direktorat Pemasyarakatan, BNPT, Densus 88 AT Polri dan juga tentunya, narapidana berisiko tinggi terorisme.

\section{Tipe Manfaat (Type of Benefit)}

Pada dasarnya tujuan utama penerapan kebijakan lapas supermaksimum security terorisme adalah untuk mengoptimalkan penerapan sistem pemasyarakatan dengan semangat revitalisasi pemasyarakatan yang sedang digalakkan oleh Direktur Pemasyarakatan. Berdasarkan tujuan lapas supermaksimum security secara eksplisit menggambarkan bahwa manfaat yang dihasilkan adalah manfaat bagi negara dan manfaat bagi narapidana terorisme berisiko tinggi.

Berdasarkan kutipan hasil wawancara dengan Kepala Lapas Kelas IIA Pasir Putih, Bapak Yandi bahwa “...Sejak penetapan lapas high risk, kita sudah men NKRI kan napi sebanyak 18 orang dan kemudian kita dipindah ke lapas maksimum. Jadi dari hal ini tentu terlihat manfaat nya, ada manfaat untuk negara."

Sependapat dengan Kepala Lapas, Pejabat di BNPT saat di wawancarai juga mengungkapkan bahwa “... Manfaat tidak hanya dari BNPT tapi negara. Kebijakan lapas supermaksimum security di pasir putih dan batu sangat membantu dan berdampak bagi narapidana diseluruh Indonesia..."

Sedangkan untuk manfaat bagi narapidana telah dikonfirmasi kepada narapidana yang pernah menghuni lapas supermaksimum security di Lapas Kelas IIA Pasir Putih yang menyebutkan bahwa kondisi (Lapas Kelas IIA Pasir Putih) luar biasa sangat ketat pengamanannya, sangat disiplin, dan mungkin bagi napi yang intropeksi itu tempat yang sangat kondusif buat menyadari kesalahankesalahan.

Sehingga dari hasil wawancara, disimpulkan bahwa manfaat yang diharapkan bagi negara adalah realisasi keamanan negara dengan optimalisasi sistem pemasyarakatan, sementara manfaat bagi narapidana terorisme berisiko tinggi adalah untuk menghilangkan radikalisasi ide-ide kekerasan. 
Perubahan yang Diwujudkan (Extend of Change)

Perubahan yang akan direalisasikan akan bermanfaat bagi pemangku kepentingan atau kepentingan yang terlibat dalam menerapkan lapas supermaksimum security di Lapas Kelas IIA Pasir Putih. Keberhasilan perubahan yang harus diwujudkan harus didukung oleh Undang-Undang sebagai dasar hukum, personel yang kompetitif di bidangnya, fasilitas dan infrastruktur, hubungan antara lembaga pelaksana dan partisipasi dari Pemerintah Pusat dan Narapidana Terorisme Berisiko Tinggi.

Gambar Grafik 1. Napiter Ikrar NKRI per

25 Juni 2019

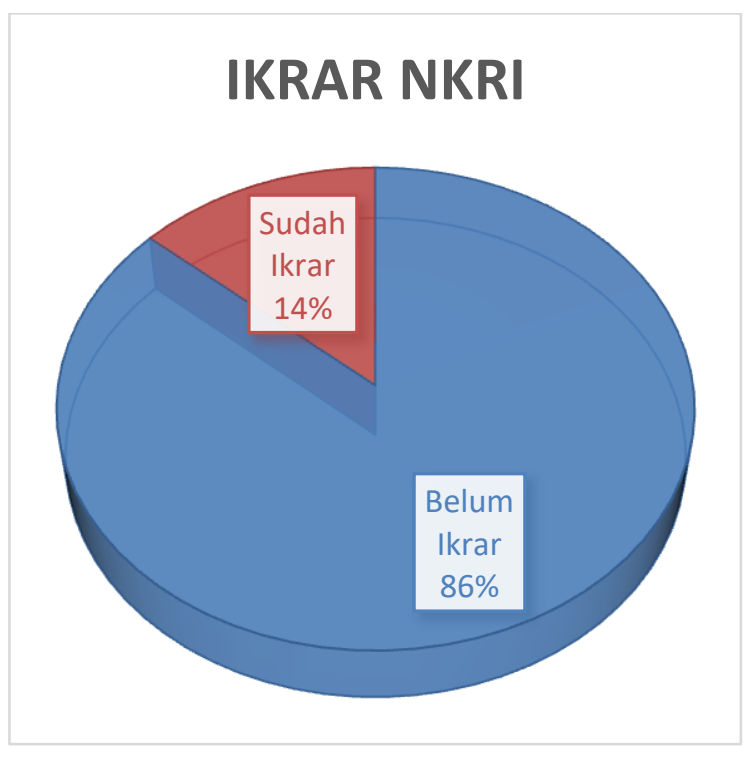

Sumber: Lapas Kelas IIA Pasir Putih, 25 Juni 2019
Dari grafik di atas, berdasarkan data dari BNPT bahwa 14\%, dengan jumlah narapidana terorisme sebanyak 18 telah menyatakan ikrar NKRI. Hal tersebut menunjukan bahwa terdapat perubahan dalam implementasi kebijakan lapas supermaksimum security di Lapas Kelas IIA Pasir Putih. Perubahan itu sendiri dimaksudkan untuk menciptakan sistem yang bertujuan untuk mengembalikan bimbingan pemasyarakatan sebagai warga negara yang baik dan juga bertujuan untuk melindungi masyarakat dari kemungkinan tindak pidana oleh bimbingan pemasyarakatan dengan melakukan deradikalisasi paham-paham ekstrim kembali ke paham NKRI, dan bagian integral dari nilai-nilai nilai yang terkandung dalam Pancasila.

\section{Kedudukan Pembuat Kebijakan (Site of Decision Making)}

Dalam melihat posisi pembuat kebijakan tidak akan terlepas dari lokasi pembuat keputusan, yang penting dalam memastikan keberhasilan implementasi kebijakan. Jika suatu kebijakan tidak memperhatikan atau tidak peduli dengan lokasi pengambilan keputusan, maka dapat dipastikan bahwa kebijakan tersebut akan mengalami masalah dalam implementasinya. Keberhasilan dalam 
persiapan terorisme keamanan kebijakan lapas supermaksimum security di Lapas Kelas IIA Pasir Putih tidak terlepas dari Keputusan Menteri Hukum dan Hak Asasi Manusia No. M.HH-07.0T.01.01 2017 tentang Penetapan Lapas Batu, Lapas Pasir Putih, Lapas Narkotika Langkat, Lapas Narkotika Kasongan, Rutan Gunung Sindur sebagai Lapas dan Rutan Khusus bagi Napi atau Tahanan Resiko Tinggi (High Risk).

Merujuk pada lampiran Peraturan Menteri Hukum dan HAM RI No. 29 Tahun 2015, bahwa ementerian memiliki beberapa direktorat jenderal dan sekretaris jenderal yang memiliki tugas fungsi yang berbeda-beda. Dengan adanya kebijakan yang dibuat oleh Menteri, hal tersebut tentu akan memaksimalkan sinergitas pengimplementasian kebijakan lapas supermaksimum yang membutuhkan tidak hanya dana operasional tapi juga SDM dan sarana dan prasarana yang mendukung jalannya operasional.

\section{Pelaksana Program}

Dalam menerapkan kebijakan, peran dan tanggung jawab pelaksana kebijakan adalah kondisi yang paling penting untuk menjamin keberhasilan implementasi mereka. Implementasi program dapat berjalan dengan baik dan mencapai target dan target yang telah ditetapkan akan tergantung pada siapa yang ditunjuk atau diberi tugas melaksanakan program. Oleh karena itu, dari Direktorat Jenderal Pemasyarakatan, Bapak Yunaedi selaku salah satu pejabat yang melakukan perumusan kebijakan menegaskan bahwa "...Dilakukan profiling petugas karena petugas tidak hanya ditempatkan di High Risk, maka nanti ada petugas yang memiliki kompetensi untuk ditempatkan di Supermaksimum, Maksimum, Mediun. Dimana assessment itu dilakukan oleh psikolog."

Pendapat diatas menegaskan bahwa pelaksana kebijakan diharapkan berasal dari orang-orang yang memiliki kapasitas untuk dapat mempengaruhi pelaksanaan kebijakan nantinya. Pada Kapasitas yang dimiliki oleh implementor diharapkan dapat meminimalisir terjadinya masalah atau hambatan dalam implementasi suatu kebijakan.

\section{Sumber Daya Berkomitmen}

Sebagaimana dipahami bahwa sumber daya yang digunakan dalam implementasi kebijakan mencakup orangorang yang memiliki kompetensi yang memadai dalam hal jumlah, kemampuan, akses ke informasi yang jelas, fasilitas dan 
infrastruktur yang tersedia, dan wewenang yang mereka miliki. Menurut Grindle (1980), implementasi kebijakan harus mencakup perhatian khusus pada faktor keragaman, ketersediaan sumber daya, struktur hubungan pemerintah, komitmen pejabat dan bahkan pengaruh dan oposisi politik. "Sumber daya yang digunakan dalam menerapkan kebijakan pemerintah cerdas secara kualitas dan kuantitas harus dipenuhi. Jika tidak tersedia, program yang diarahkan ke perubahan yang lebih baik akan terhambat. Sehingga waktu yang dibutuhkan tidak sesuai dengan harapan para penerima layanan. Sumber daya aparatur dan sumber daya lain untuk mendukung implementasi kebijakan harus dipenuhi sesuai dengan kebutuhan organisasi sesuai dengan standar yang ada. Adapun sumber daya yang tersedia dalam pelaksanaan lapas supermaksimum security di Lapas Kelas IIA Pasir Putih, dapat dilihat dari jumlah personel, kemampuan personel, sarana dan prasarana serta jumlah biaya.

Berdasarkan uraian di atas, dapat disimpulkan bahwa implementasi kebijakan masih menghadapi beberapa masalah dalam hal sumber daya yang digunakan.

\section{Konteks Implementasi}

Menurut Grindle (1980), Konteks Implementasi mencakup 3 sub kategori berikut: 1) kekuasaan, minat, dan strategi aktor yang terlibat; 2) karakteristik institusi dan rezim; 3) kepatuhan dan responsif.

\section{Kekuatan, Minat, dan Strategi Aktor yang Terlibat}

Berdasarkan penjelasan di atas, jelas bahwa penerapan kebijakan terorisme lapas supermaksimum security di Lapas Kelas IIA Pasir Putih masih menghadapi beberapa masalah dengan tidak adanya pemahaman yang sama atau kepentingan para aktor yang terlibat dan masih ada kelemahan dalam strategi yang diadopsi oleh para aktor kebijakan.

Seorang informan menyebutkan bahwa belum optimalnya kekuatan petugas yang berdinas di lapas supermaksimum security. Dari data yang diambil dilapangan bahwa per 25 Juni 2019 jumlah pegawai di lapas sebanyak 94 orang dimana kebutuhannya seharusnya 285 orang. Disisi lain, disampaikan bahwa masih ada aturanaturan terkkait penilaian narapidana kategori resiko tinggi terorisme yang belum disahkan sampai dengan bulan Juli 2019, sehingga para pelaksana dilapangan 
harus menggunakan instrument yang ada, yang masih belum tepat instrumennya untuk kejahatan terorisme.

Institusi dan Rezim

Karakteristik institusi dan otoritas dalam mengimplementasikan setiap detail bisnis membutuhkan transparansi dan kejelasan sehingga pelaksana dapat memahaminya dan tidak menyebabkan kebingungan. Lokus pelaksanaan rincian urusan harus jelas dan dapat dipahami oleh semua elemen pelaksana, sehingga ada satu kesatuan tindakan untuk mewujudkan kebijakan yang lebih sesuai dengan harapan bersama.

Dilihat dari website ditjenpas.go.id, bahwa fungsi Direktorat Jenderal Pemasyarakatan salah satunya yaitu memberikan bimbingan dan evaluasi. Hal itu menunjukan bahwa karakteristik yang diharapkan tersebut melekat pada instansi dan disisi lain dengan hadirnya Dirjen untuk langsung ke lapangan memberikan hasil yang baik bagi kinerja pelaksana dalam pengimplementasian kebijakan ini.

\section{Kepatuhan dan Responsif}

Dalam implementasi kebijakan publik, ada hal-hal yang harus diperhatikan, tidak hanya bagaimana bisa mensosialisasikan kebijakan tetapi bagaimana pemerintah dapat memastikan bahwa aparaturnya mematuhi kebijakan tersebut. Terkait hal tersebut, Akademisi UI Bapak Solahudin menyampaikan sebagai berikut:

"(Kepatuhan petugas) Relative bagus, kalo disana sini ada permasalahan itu masih wajar. Dan yang perlu diperbaiki adalah insentive nya, lapas high risk tapi pemasukannya low income. Kasihan dunk, resikonya kan tinggi, incomenya rendah. Insentive harus dibenahi. Biar jangan sampai orang-orang yang memiliki kapasitas ini dengan resiko yang tinggi malah meninggalkan pekerjaan ini, ke lapas2 umum."

Pernyataan Akademisi UI tersebut juga senada dengan pernyataan dari Bapak Yunaedi yang menyatakan " ...Sangat bagus, mereka masih berpenganan dengan SOP. Kalo ada sedikit pelanggaran, masih dalam batas otelansi untuk dibenahi."

Penyataan-penyataan tersebut menandakan bahwa kepatuhan tercapai dan mengimplementasikan aturan yang ditetapkan, implementasi kebijakan akan efektif. Kepatuhan dan responsif pelaksanaan dalam kebijakan kemudian dapat dilihat dari hasil pemantauan dan kurangnya masalah yang muncul di lapangan. 


\section{KESIMPULAN}

Kebijakan lapas supermaksimum security di Lapas Kelas IIA Pasir Putih untuk narapidana terorisme risiko tinggi dari pembahasan di atas dapat disimpulkan bahwa penerapan kebijakan lapas supermaksimum security di Lapas Kelas IIA Pasir Putih untuk narapidana terorisme berisiko tinggi dalam konteks mengoptimalkan sistem pemasyarakatan yang dimasukkan sebagai bagian dari revitalisasi hukuman umumnya memiliki dampak positif, berdampak pada kelompok sasaran.

Isi kebijakan menunjukkan kondisi yang baik, tetapi Konteks implementasi menunjukkan kondisi yang kurang optimal. Disisi lain implementasi kebijakan yang baru berjalan 2 tahun, menjadi pendorong baik instansi terkait untuk terus melakukan perbaikan demi mencapai hasil yang optimal.

\section{DAFTAR PUSTAKA}

Creswell, John W. 2014. Research design: qualitative, quantitative, and mixed methods approaches Fourth Edition. Amerika: Sage Publication Inc.

Firdaus, Insan. 2017. Penempatan Narapidana Teroris di Lembaga Pemasyarakatan.. Jurnal Penelitian Hukum DE JURE,
ISSN 1410-5632 Vol. 17 No. 4, hlm. $429-443$.

Grindle, Marilee S. 1980. Politics and Policy Implementation in the Third World. Princeton: Princeton University Press.

Hassan, Muhammad Haniff dan Yasin, Nur Azlin Mohamed. 2012. Indonesian Prisons: A Think Tank for Terrorists. Counter Terrorist Trends and Analyses, Vol. 4, No. 8. https://www.jstor.org/stable/2 $\underline{6351080}$.

Henningsen, R. J., Johnson, W. W., \& Wells, T. 1999. Supermax prisons: Panacea or desperation?. Corrections Management Quarterly.

Laporan IPAC (Institute for Analysis of Conflict) Nomor 34 Tanggal 14 Desember 2016.

Mears, Daniel P.. 2008. An Assessment of Supermax Prisons Using an Evaluation Research Framework. The Prison Journal Volume 88 Number 1 March 2008 43-68. http://tpj.sagepub.com.

Miles, M.B., Huberman, A.M. 1994. Qualitative Data Analysis, 2nd ed. USA: Sage Publication.

Riveland, C. 1999. Supermax prisons: Overview and general considerations. Washington, DC: U.S. Department of Justice, National Institute of Corrections.

\section{Peraturan}

Direktorat Jenderal Pemasyarakatan Nomor PAS-19.PR.01.01 Tahun 2015 Tanggal 11 Juni 2015 
Tentang Rencana Strategis

Direktorat Jenderal

Pemasyarakatan 2015-2019.

Direktorat Jenderal Pemasyarakatan, Standar Pembinaan Narapidana Teroris, 2015.

Keputusan Menteri Hukum dan Hak Asasi Manusia RI No. M.HH-05. OT.01.10 tanggal 30 Desember 2010 tentang Organisasi dan Tata Kerja Kementerian Hukum dan Hak Asasi Manusia.

Keputusan Menteri Hukum dan HAM No. M.HH-07.0T.01.01 Tahun 2017 tentang Penetapan Lapas Batu, Lapas Pasir Putih, Lapas Narkotika Langkat, Lapas Narkotika Kasongan, Rutan Gunung Sindur sebagai Lapas dan Rutan Khusus bagi Napi atau Tahanan Resiko Tinggi (High Risk).

Keputusan Menteri No. M.HH02.PK.01.02.02 Tahun 2017 tentang Pedoman Kerja Lembaga Pemasyarakatan khusus bagi Narapidana Resiko Tinggi (High Risk) Kategori Teroris.

Pedoman Kerja Lapas Khusus Bagi Napi High Risk Kategori Teroris

Peraturan Presiden No 44 Tahun 2015.

Undang-Undang No. 5 Tahun 2018.

Undang-undang Nomor 12 tahun 1995 tentang Pemasyarakatan. 